\title{
ZTRACENA V PRAZE: POSTOJE KOLEMJDOUCÍCH K OSOBĚ MUSLIMSKÉHO VYZNÁNÍ
}

\author{
KATEŘINA SMUŽANICA, KLÁRA STOJANOVÁ
}

\begin{abstract}
Při současné geopolitické situaci v Evropě vyvstává otázka, jaké jsou postoje vůči osobám s muslimským vyznáním. Tato práce se zabývá právě postoji lidí v Praze k cizince, u které je její muslimské vyznání zjevné v porovnání s cizinkou, u které na první pohled není možné určit konkrétní světonázor. Celkem bylo osloveno sto osob. Padesát z nich figurantkou v roli muslimky, dalších padesát pak stejnou figurantkou v roli „,běžné“ cizinky. Reakce osob byly hodnoceny na škále od jedné do pěti. Postoj osob k figurantce $\mathrm{v}$ roli muslimky se statisticky významně nelišil od postoje $\mathrm{k}$ figurantce $\mathrm{v}$ roli cizinky $(\mathrm{p}=0,124)$. Další aspekty této problematiky, např́iklad rozdíl mezi hodnocením Čechů a cizinců, jsou diskutovány.
\end{abstract}

Klíčová slova: postoje, muslim, cizinci, Praha, prosociální chování https://doi.org/10.14712/23366486.2018.3

\section{Úvod}

Evropa od roku 2015 čelí migrační krizi, při které zejména uprchlíci z Blízkého a Středního východu hledají v Evropě útočiště před nepříznivou válečnou situací v jejich domovských státech. Tito uprchlíci jsou většinou osoby aktivně praktikující islám.

V křest’anské Evropě se zájem o islám zvýšil zejména po teroristických útocích 11. zář́i (Allen, Nielsen, 2002), které vyvolaly vlnu negativního, ale i pozitivního zájmu. V České republice, kde dlouhodobě žije pouze asi 22 tisíc muslimů ${ }^{1}$, jsou názory na muslimskou komunitu ambivalentní a z velké části jsou ovlivňovány mylnými informacemi. Na situaci migrační krize parazitují zejména různá hnutí a politické strany, jež propagují nenávist vưči islámu (Islám v České republice nechceme, Blok proti islamizaci a podobné). Tato hnutí a politické strany získávají značnou podporu. $V$ dnešní době se Češi totiž obecně nejvíce obávají právě migrace (31\%). Za dvě největší reálné hrozby pro mír a bezpečnost v České republice občané považují teroristy ( $71 \%$ občanů) a uprchlíky z jiných zemí (63\% občanů) (Červenka, 2016).

\footnotetext{
1 Při posledním sčítání osob v roce 2011 se jednalo přibližně o 3 tisíce muslimů, ovšem sociologové toto číslo považují za podhodnocené. Sociolog Karel Černý mluví právě o čísle 22 tisíc (Biben, 2015).
} 


\section{Teoretická východiska}

Každý člověk se zařazuje do určité referenční skupiny, tedy do skupiny, se kterou se identifikuje. Na základě této identifikace se pak jako lidé ř́́díme jistými normami a přebíráme soubory přesvědčení, postojů a chování, o kterých se domníváme, že jsou správné. Ve chvíli, kdy přebíráme tyto různé ideologie za své a zařadíme je do svého žebříčku hodnot, vzniká tzv. internalizace (Atkinsonová et al., 2012). Konkrétní reakce osob, které pramení z postojů, jsou také středobodem tohoto výzkumu.

Fishbein a Ajzen, kteří v 70. letech vytvořili model postojů, vnímají postoj jako označení emocionální přitažlivosti, anebo odpudivosti objektu pro danou osobu. Postoj vzniká na základě určitého počtu přesvědčení, která tento postoj determinují. Lidské chování je vysvětleno ve vztahu k přesvědčení $\mathrm{v}$ tom smyslu, že reprezentuje informace, které člověk má o světě, ve kterém žije (Výrost, Slaměník, 1997). Přesvědčení je zejména tvořeno vztahem osoby k okolnímu světu, její subjektivní normou, informacemi, které má o světě a jejími záměry. Mnohost těchto jednotlivých přesvědčení tvoří postoje.

Otázkou je, zdali postoje anticipují naše skutečné chování. Touto problematikou se zabýval např́klad LaPiere, který ve 30 . letech 20 . století v USA, v době charakteristické hostilitou Američanů vůči Číňanům, zkoumal pár mladých Č́iňanů, kteří žádali o ubytování v několika hotelech. Výsledky výzkumu se radikálně lišily. Při osobním dotazování byl čínský pár odmítnut pouze jednou, avšak když LaPiere obeslal tytéž hotely dopisem s otázkou, zdali by ubytovali čínský pár, dostal $92 \%$ negativních odpovědí (LaPiere, 2010).

Zpochybnění předpokladu, že postoje anticipují chování, podnítilo novou vlnu výzkumů, která se zaměřovala na to, zdali existují specifičtější podmínky, které určují, jak se jedinec zachová v určité situaci. $\mathrm{Z}$ těchto výzkumů byly podpořeny následující body. Postoje předcházejí chování:

- pokud jsou silné,

- pokud mají úzký vztah k predikovanému chování,

- v prípadě, že jsou založené na osobní zkušenosti,

- za předpokladu, že si daný jedinec své postoje uvědomuje (Atkinsonová et al., 2012).

Při hodnocení určitých objektů hrají také roli předsudky. Předsudky mívají velmi silný emoční náboj a slabou kognitivní složku. Kognitivní složkou se míní souhrn informací, $\mathrm{k}$ němuž přiřazujeme vlastní názor. Často vznikají bez dostatečné předešlé znalosti a jejich typickým znakem je zaujatost vůči rozumovým argumentům. Jejich součástí bývají stereotypy (Vágnerová, 2005).

Pokud nějakou informaci stereotypizujeme, implicitně ji kategorizujeme a srovnáváme s našimi předešlými vzpomínkami či zkušenostmi. Pro stereotypizaci je charakteristické, že máme určitá schémata (např. podle rasy, věku, pohlaví atd.) a třídíme osoby do skupin podle těchto tělesných atributů. Různé stereotypy mohou vyvolávat různé asociace, na základě kterých můžeme jednat (Atkinsonová et al., 2012). Např́iklad: „Muslim má u sebe určitě bombu nebo minimálně pistoli, raději utíkám.“

Anti-islamistické postoje jsou často dostupným odrazovým můstkem k obecným předsudkům. Celkově můžeme rozlišit anti-islamistické postoje od obecnějších postojů proti-cizineckých. Tyto postoje jsou nicméně propojeny. Člověk s celkově xenofobními, proti-cizineckými názory bude pravděpodobně zastávat i anti-muslimský postoj (Spruyt, Elchardus, 2012). 
Důležitý pro náš výzkum je také celkový „koncept cizince“ (Lofland, 1973). Někteří autoři předesílají názor, že pojem cizinec (stranger) je vytvořen na základě strachu. Tento strach by mohl vyvěrat z nemožnosti předpovídat, jaký cizinec je. Lidé mají navíc i určitá očekávání, která jsou poplatná kultuře, ve které žijí. Když se těmto očekáváním něco vymyká, lidé projikují svůj strach do skupin či individuálních osob, a to zejména do těch jednotlivců nebo skupin, jež jsou v kontextu dané kultury odlišní (Harris et al., 2016). V tomto konceptu je cizinec vnímán jako nepředvídatelný a obávaný činitel, vưči kterému jsou lidé předpojatí. Strach z cizince (který pak lidé dále promítají do skupin a jednotlivců) může být vyvolán mimo jiné pouze fyzickými charakteristikami (Heringa, Bolt \& Dijst, 2013). Takovou fyzickou charakteristikou je v Evropě např́íklad velmi kontroverzní zahalování muslimských žen. Šátek na hlavě kolemjdoucí ženy tedy může okamžitě vyvolat obavy a zaprríčinit, že tato kolemjdoucí osoba bude konceptualizována jako cizinec (stranger). Je zajímavé, že ač je to na první pohled muslimská žena, která je označena za cizince, je to především chování muslimského muže, které je vnímáno jako „cizí“‘ (strange) (Harris et al., 2016).

Hostilitu vůči muslimům v sekularizovaných společnostech se snaží vysvětlit nejméně dvě teorie. První z nich hovoří o „náboženském soupeření“ (religious competition) mezi islámem a minoritou ortodoxních protestantů. Druhá z nich hostilitu vysvětluje rozdílnými hodnotami muslimů a majoritních skupin osob, které nejsou stoupenci žádného náboženství. Výsledky studie Egberta Riberrinka, Petera Achterberga a Dicka Houtmana (2016) naznačují, že i když je tolerance vůči muslimům v sekularizovaných státech obecně vyšší než ve státech vázaných na náboženskou ideologii, nejsilnější anti-muslimské postoje vyjadřují osoby bez vyznání, které pocházejí ze sekulárních států.

Spruyt a Elchardus (2012) zmiňují tři důvody, proč jsou postoje vůči muslimům více náchylné ke stereotypizaci. Prvním důvodem je rozsáhlá kritika muslimské komunity pro nedodržování konsenzuálních společenských norem, jako je rovnost, práva jednotlivce, demokracie, bezpečnost a tolerance. Tato kritika se hojně objevuje v médiích a v rámci veřejných debat. Pravděpodobnost stereotypizace stoupá, pokud jsou tyto debaty navíc podpořeny ze strany různých politických stran a hnutí, prŕípadně akademické obce. Muslimové jsou kritizováni současně jako náboženská i etnická skupina (Esposito, Kalin, 2011), což je druhým důvodem pro možnou, navíc kumulativní, stereotypizaci. Třetím důvodem je určité „třeni““ mezi muslimy a „nemuslimy“ v Evropě, které spočívá v rozdílných normách, postojích a způsobu života.

Výzkum Spruyta a Elcharduse z univerzity v Bruselu (2012) podpořil hypotézu, že anti-muslimské postoje (islamophobia) jsou více rozšířené než proti-cizinecké postoje (xenophobia).

Cílem naší práce bylo zjistit, jak se budou lišit reakce osob při setkání s cizinkou s jasným muslimským vyznáním (dále jen ,muslimka“) a cizinkou bez vyznání (dále jen „cizinka“). Zajímalo nás, jaké kognitivní schéma, tedy jaké utříděné přesvědčení, používáme vůči cizincům s jasným muslimským vyznáním. Zvláště, zda toto schéma je či není výrazně stereotypizováno, tedy zda je ve vnímání muslimů jasný stereotyp. Zároveň jsme si byly vědomy, že reakce lidí mohou ovlivnit také jiné faktory (situační, společenské atp.), tedy že konativní stránka postojů se může lišit od jejich reálného postoje, př́padně kognitivního a emočního naladění. 


\section{Výzkumné předpoklady}

Na základě výše zmíněného, byly před samotným výzkumem formulovány tyto předpoklady:

1) Postoj k muslimce bude jiný než postoj $\mathrm{k}$ cizince.

2) Vůči muslimce bude zaznamenána vyšší míra hostility.

3) Př́stup k muslimce se bude lišit mezi cizinci a Čechy.

4) Př́stup k cizince se nebude mezi Čechy a cizinci lišit.

5) Př́stup vůči muslimce se nebude lišit napříc pohlavím.

6) Př́ístup vůči cizince se nebude lišit napříč pohlavím.

7) Př́stup vůči muslimce se bude lišit mezi jednotlivci a skupinami.

8) Př́stup vůči cizince se nebude lišit mezi jednotlivci a skupinami.

\section{Metoda}

\section{EXPERIMENT V PŘIROZENÝCH PODMÍNKÁCH}

\section{Výzkumný soubor}

Figurantka oslovila 50 náhodně vybraných chodců (za chodce považujeme nejen jednotlivce, ale i skupiny) na ulici Na Př́kopě v Praze v roli muslimky a dalších 50 náhodně vybraných chodců oslovila na totožném místě v roli cizinky. Dohromady tedy ve výzkumu participovalo 100 účastníků. Během výzkumu bylo rozlišováno mezi cizinci a Čechy a dále mezi jednotlivci, dyádami a skupinami.

\section{Popis sběru dat}

Výzkum jsme realizovaly s pomocí figurantky (spoluautorky práce, 23 let), která se účastníků dotazovala na cestu na konkrétní lokaci. Figurantka oslovila každého čtvrtého chodce, aby zamezila nežádoucím vlivům, např́íklad preferenci určitých osob. Účastníci si nebyli předem vědomi toho, že se jedná o výzkum. Po interakci figurantky a náhodného člověka udělil doprovodný tým hodnocení danému účastníkovi na základě pozorované interakce a předem sestavené škály číslem 1-5 (podrobněji viz dále). Doprovodný tým tvořily dvě mladé ženy ve věku 20 let (jedna z nich je spoluautorkou práce). Dvoučlenný doprovodný tým měl zajistit co největší objektivitu hodnocení.

\section{Postup sběru dat a jejich zpracování}

Figurantka si dne 11. 11. 2016 v 9:30 s pomocí dobrovolnice (praktikující české muslimky, aby byla zajištěna určitá autenticita) oblékla kostým, který se skládal především z tradičního muslimského šátku (hidžábu) a výrazně evokoval osobu praktikující islám. Na ulici Na Př́kopě se pak figurantka každého čtvrtého kolemjdoucího anglicky dotazovala na cestu na Václavské náměstí, př́ípadně na cestu na Náměstí Republiky (Palladium).

F: Excuse me! How can I get to Wenceslas square/Palladium?

O dva týdny později (25. 11. 2016), ve stejný čas a na stejném místě, byl postup zopakován. Tatáž figurantka se opět stejným způsobem dotazovala anglicky na cestu obdobným způsobem vybraných kolemjdoucích, nyní již však ve svém civilním oblečení, připomínala tedy běžnou zahraniční turistku. 
Kvantitativní data, získaná ve dvou prrípadech, jsme následně zpracovaly pomocí deskriptivní a inferenční statistiky. Reakce kolemjdoucích hodnotil doprovodný výzkumný tým na škále od 1 do 5 :

Tabulka 1 Hodnocení reakcí

\begin{tabular}{|c|c|c|}
\hline HODNOCENÍ & POPIS & BLIŽŠÍ VYSVĚTLENÍ \\
\hline 1 & $\begin{array}{l}\text { Nepřátelská reakce, } \\
\text { bez pomoci. }\end{array}$ & $\begin{array}{l}\text { Osoba zjevně slyšela otázku figurantky a rozhodla se } \\
\text { nereagovat, často s hostilní doprovodnou reakcí. }\end{array}$ \\
\hline 2 & $\begin{array}{l}\text { Nepř́telská reakce, } \\
\text { pomoc. }\end{array}$ & $\begin{array}{l}\text { Osoba zjevně slyšela otázku figurantky a rozhodla se } \\
\text { reagovat, avšak s hostilní doprovodnou reakcí; např. úsečná } \\
\text { odpověd', mračení apod. }\end{array}$ \\
\hline 3 & $\begin{array}{l}\text { Přátelská reakce, } \\
\text { běžná pomoc. }\end{array}$ & $\begin{array}{l}\text { Na položenou otázku figurantka získala přiměřenou odpověd’, } \\
\text { napřr. „P Půjdete rovně a budete tam, nemǔžete minout.“ }\end{array}$ \\
\hline 4 & $\begin{array}{l}\text { Velmi přátelská reakce, } \\
\text { běžná pomoc. }\end{array}$ & $\begin{array}{l}\text { Na položenou otázku figurantka získala přiměřenou } \\
\text { odpověd’, kterou provázely velmi přátelské projevy, např́. } \\
\text { vřelý úsměv, delší odpověd’, přátelský vtip, pozitivní „body } \\
\text { language“ apod. }\end{array}$ \\
\hline 5 & $\begin{array}{l}\text { Velmi přátelská reakce, } \\
\text { pomoc nad rámec } \\
\text { běžné pomoci. }\end{array}$ & $\begin{array}{l}\text { Reakce byla nad očekávání, např. zapředení rozhovoru, } \\
\text { nabídka doprovodu do cílové lokace, spontánní pomoc, } \\
\text { vyhledání trasy na vlastním telefonu. }\end{array}$ \\
\hline
\end{tabular}

Figurantka oslovila každého čtvrtého kolemjdoucího. V jednom př́padě byla, jako čtvrtá kolemjdoucí, oslovena osoba bez domova, která nereagovala na otázky figurantky (pouze se pokusila vyžebrat nějaké peníze). Tato osoba byla z výzkumu vyřazena. V žádném jiném př́ípadě se tak nestalo.

\section{Analýza dat}

Data byla analyzována pomocí statistického softwaru JASP 0.8.0.0.

\section{Výsledky}

\section{Předpokládáme, že postoj $k$ muslimce bude jiný než postoj $k$ cizince.}

H0: Postoje k muslimce a cizince se neliší.

HA: Postoje k muslimce a cizince se liší.

Hlavní otázkou našeho výzkumu bylo, zda se statisticky významně odlišuje př́stup k muslimce a běžné cizince. Porovnaly jsme hodnocení muslimky a cizinky pomocí chí kvadrát testu nezávislosti, tedy testu v kontingenční tabulce. Mediánem, který je vhodným ukazatelem střední hodnoty pro ordinální data, je hodnocení 3 (přátelská reakce, běžná pomoc) v obou prípadech - tedy jak u muslimky, tak u cizinky.

Postoj osob k muslimce se statisticky významně nelišil od postoje $\mathrm{k}$ cizince $\chi^{2}(4, N=99)=7,239 ; p=0,124$. Alternativní hypotéza nebyla podpořena, naše data svědčí ve prospěch nulové hypotézy.

\section{Předpokládáme, že vưči muslimce bude zaznamenána vyšší míra hostility.}

H0: Hostilita vưči muslimce a cizince se neliší.

HA: Hostilita vůči muslimce bude vyšší. 
Z důvodů velkého strachu a obav z imigrace a terorismu, které jsou spojovány s islámem, jsme formulovaly náš druhý předpoklad. Mínily jsme, že vůči muslimce budou dotázané osoby vyjadřovat vyšší míru hostility. Tato hostilita se bude projevovat neochotou pomoci, případně pomocí bez projevů prátelství. Tedy, že u muslimky bude vyšší míra hodnocení 1 (nepřátelská reakce, bez pomoci), př́ípadně 2 (nepřátelská reakce, pomoc), než u cizinky, u které jsme předpokládaly prevalenci spíše neutrálních, př́ípadně přátelských reakcí.

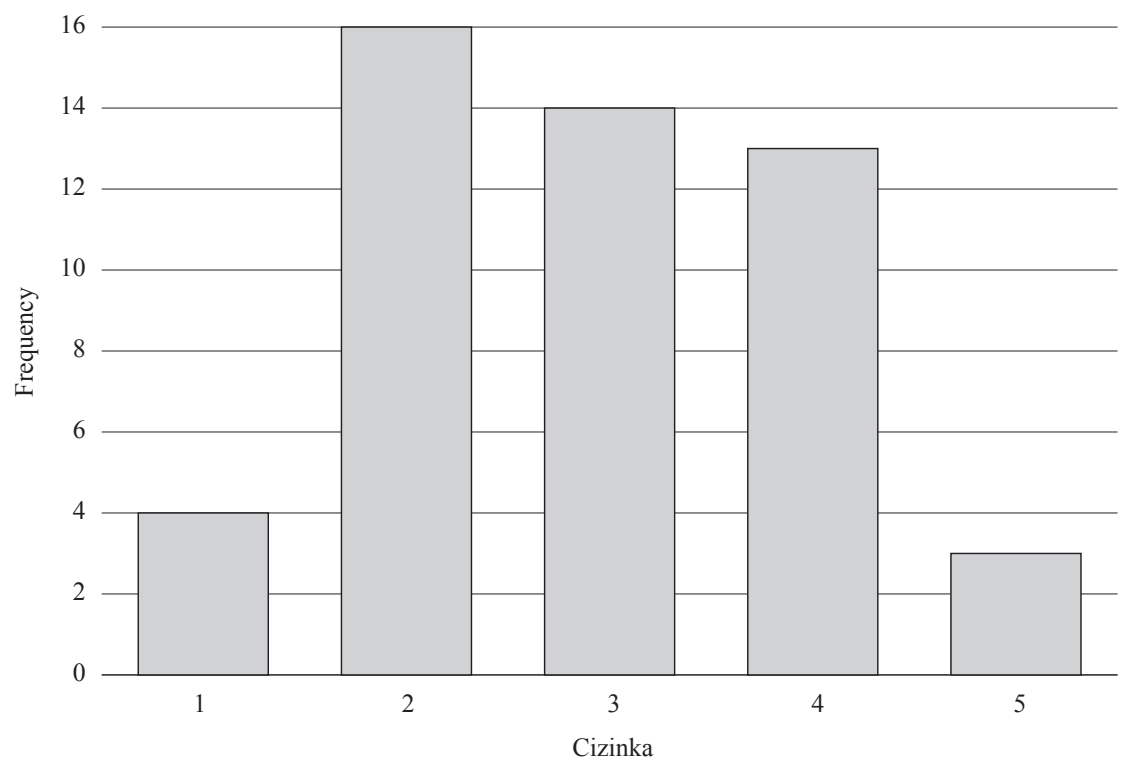

Graf 1 Celkové hodnoceni cizinky

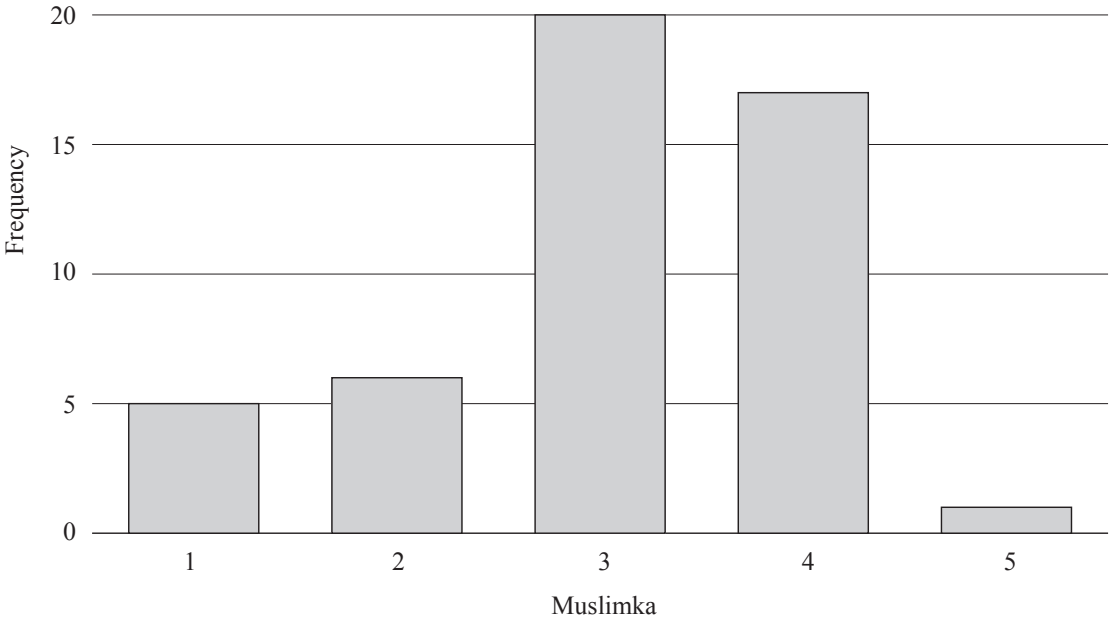

Graf 2 Celkové hodnocení muslimky 
Hodnocení muslimky byla převážně neutrální, tedy modus i medián je hodnota 3 (celkem 40 \% osob zaujalo k muslimce neutrální postoj), druhým nejčastějším hodnocením bylo hodnocení 4 , tedy velmi přátelská reakce, běžná pomoc.

Nejčastějším hodnocením cizinky (modus) byla hodnota 2 , tedy 32 \% osob vykazovalo nepřátelskou reakci, přestože cizince poskytli pomoc. Druhou nejčetnější reakcí byla rekce neutrální.

Z celkového počtu 99 probandů muslimce nepomohlo $10 \% \mathrm{z}$ nich, cizince nepomohl relativně podobný počet dotázaných $-8 \%$. Vůči muslimce byla projevena velmi přátelská reakce s nadstandartní pomocí (hodnocení 5) pouze v jednom prŕípadě, vůči cizince celkem ve třech př́ipadech.

Pro účely tohoto srovnání jsme data testovaly Mann Whitneyho U testem: $U=1141,0$; $\mathrm{p}=0,436$. Zamítly jsme tedy alternativní hypotézu, že vůči muslimce bylo projeveno více hostilních reakcí.

\section{Předpokládáme, že přístup k muslimce se bude lišit mezi cizinci a Čechy.}

H0: Př́ístup k muslimce se mezi cizinci a Čechy neliší.

HA: Př́istup k muslimce se mezi cizinci a Čechy liší.

Třetí otázka, se kterou jsme pracovaly byl předpoklad, že cizinci budou k muslimce ochotnější než Češi. Tento předpoklad jsme vytvořily na základě pojmu identifikace (viz výše). Domníváme se, že cizinci budou přistupovat $\mathrm{k}$ muslimce přívětivěji z toho důvodu, že jsou již povětšinou na muslimskou kulturu zvyklí. Ve většině států, ze kterých pocházejí cizinci cestující do České republiky, dle statistik jsou to nejvíce turisté z Německa, Itálie, Velké Británie, Ruska, Francie a USA je také procentuálně výrazně větší muslimská menšina (Ministerstvo pro místní rozvoj ČR, Czech tourism, 2015).

V prvním bloku výzkumu (,muslimka“) bylo osloveno 16 cizinců a 33 Čechů. U jedné ženy se nepodařilo zjistit, jaké je národnosti.

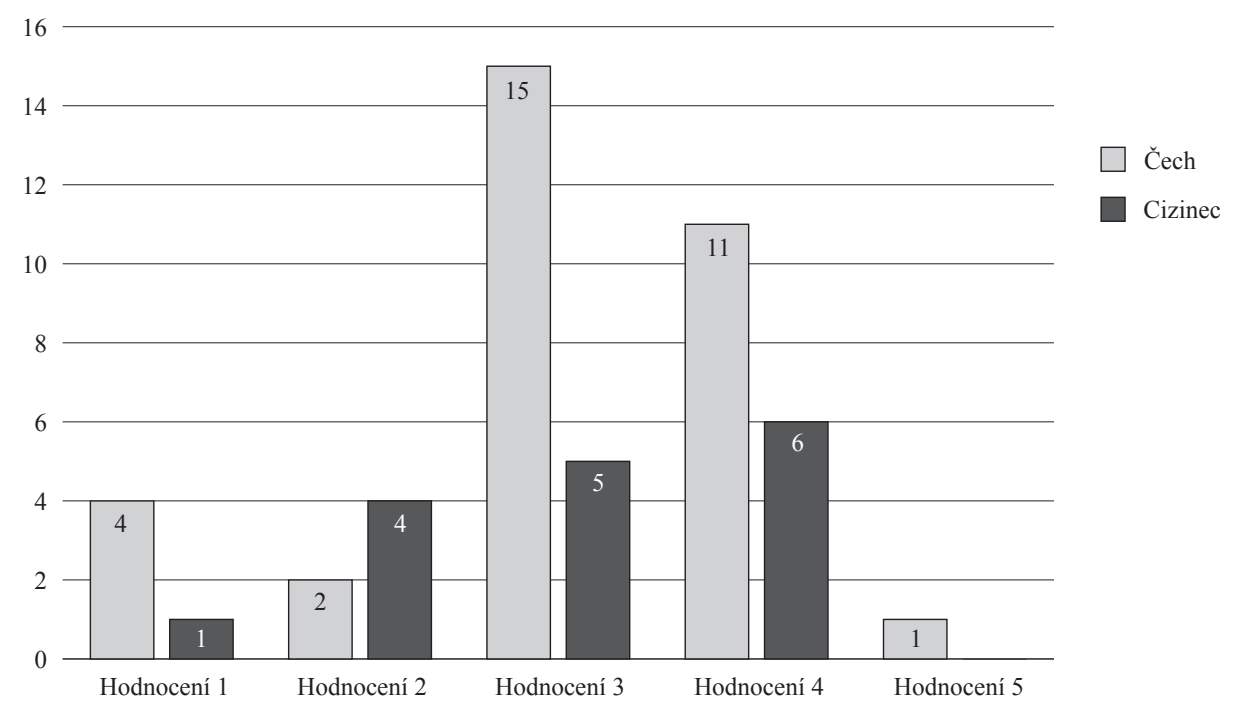

Graf 3 Hodnocení muslimky 
Když vezmeme v potaz nepoměr probandů ve skupinách cizinec vs. Čech, nespatřujeme žádné významné rozdíly v hodnocení průměrných (tzn. 3) a nadprůměrných (tzn. 4 a 5). Co se podprůměrných (tzn. 1 a 2 ) hodnocení týče, cizinci reagovali podprůměrně celkem v pěti př́padech, tedy podobně jako Češi ( $v$ šesti prŕípadech), avšak u cizinců to tvoří jednu třetinu všech hodnocení, zatímco u Čechů je to méně než jedna pětina všech hodnocení (z důvodu rozdílné velikosti skupin). Nejčetnějším hodnocením (modus) bylo u cizinců hodnocení 4 (37,5\%), zatímco u Čechů to bylo hodnocení 3 (45,5\%).

Tento fakt nepodpořil naši alternativní hypotézu, že cizinci budou k muslimce přistupovat jinak než Češi, a dokonce se zdá, že je tomu v našem případě přesně naopak. Češi v našem vzorku reagovali méně negativně.

Mezi hodnocením nebyl zjišsěn statisticky signifikantní rozdíl, $U=251,5 ; p=0,785$, zamítáme tedy alternativní hypotézu, že by $\mathrm{k}$ figurantce $\mathrm{v}$ roli muslimky cizinci přistupovali jinak než Češi.

Zajímavou humornou povahu měly některé individuální reakce osob, které nelze vyčíst z prosté deskriptivní statistiky. Někteří muži přistupovali k figurantce, která byla oblečená za muslimku, velmi vřele. Jeden muž na figurantku sáhl, chtěl ji obejmout a vykazoval jisté známky sympatií, které ovšem nebyly oboustranné, a to nejen z důvodu, že je v rámci muslimské kultury nepřijatelné, aby na ženu na ulici sahal cizí muž.

Překvapující byl také milý a ochotný prrístup starší paní o holi, která na angličtinu odpovídala velmi klidně a pomalu česky, usmívala se a pokyvovala holí směrem, na který se figurantka $\mathrm{v}$ roli muslimky tázala.

Nejvyhrocenější reakcí byla reakce mladé ženy, která po střetnutí se s figurantkou v roli muslimky začala utíkat, několikrát se otočila nazpět a až po 50 metrech běhu se zastavila a šla normálním krokem.

Nejzajímavější reakcí byla reakce muže a ženy, kteří se sami aktivně „bloudící“ figurantce v roli muslimky rozhodli pomoci. Vzápětí se ukázalo, že se jednalo o členy náboženské společnosti Svědků Jehovových, a kromě pomoci se také snažili figurantku pozvat na jejich konferenci.

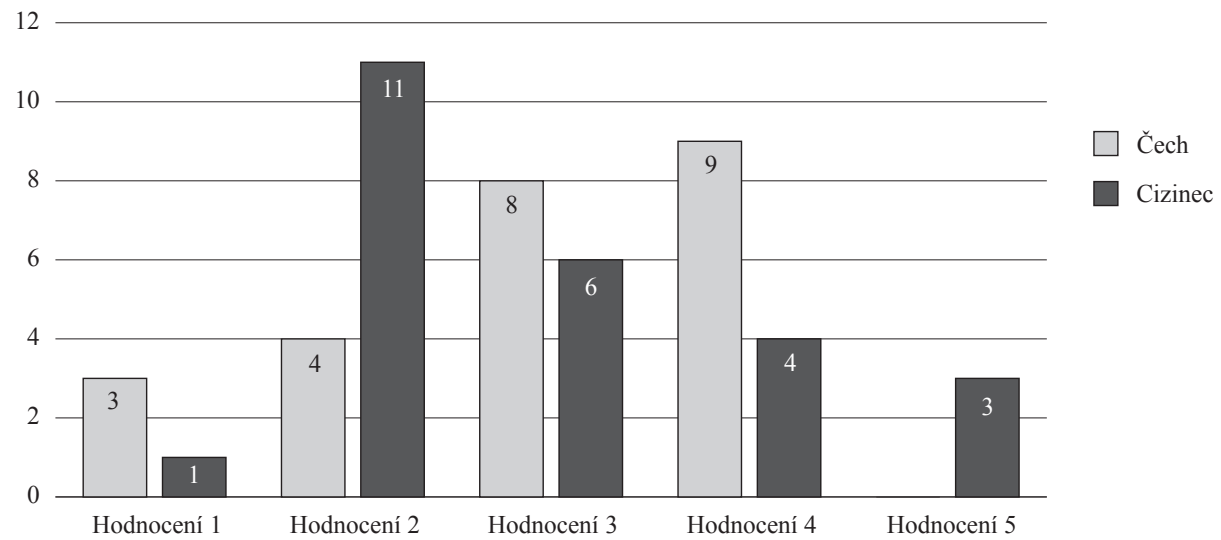

Graf 4 Hodnocení cizinky 


\section{Předpokládáme, že př́stup k cizince se nebude mezi Čechy a cizinci významně}

lišit.

H0: Př́istup k cizince se mezi cizinci a Čechy neliší.

HA: Př́ístup k cizince se mezi cizinci a Čechy liší.

Ve druhém bloku výzkumu (,cizinka“) bylo osloveno 24 Čechů a 25 cizinců.

Cizinci, kteří reagovali na figurantku v roli cizinky, byli méně přivětiví než Češi. Reagovali celkem 12krát podprůměrně (48 \%), zatímco Češi takto reagovali 7krát $(29,17 \%$ ). Nejčetnějším hodnocením (modus) bylo u cizinců hodnocení 2 (44 \%), zatímco u Čechů to bylo hodnocení 4 (37,5 \%). Překvapivě však nejlépe reagovali právě cizinci (celkem 3 krát), zatímco Češi takto nereagovali ani jednou.

Hypotézu, že př́stup $\mathrm{k}$ figurantce $\mathrm{v}$ roli cizinky se nebude mezi cizinci a Čechy významně lišit, jsme podpořily. Mezi hodnocením Čechů a cizinců tedy nebyl statisticky signifikantní rozdíl $\mathrm{U}=272,5 ; \mathrm{p}=0,575$.

$\mathrm{V}$ tomto př́padě, kdy byla figurantka oblečena klasickým způsobem a jednala jako cizinka bez zjevného vyznání, jsme se nesetkaly s žádnými zajímavými reakcemi. Subjektivně na nás však prístup lidí působil více odměřeně.

\section{Předpokládáme, že př́stup vůči muslimce se nebude lišit napříč pohlavím.}

H0: Přístup vi̊či muslimce se neliší např́ič pohlavím.

HA: Př́stup vůči muslimce se liší napříč pohlavím.

Naším pátým předpokladem bylo, že přístup vůči muslimce se nebude lišit např́íc pohlavím. Co se týče prvního bloku (,,muslimka“), bylo osloveno 15 žen a 19 mužủ. Mezi uvedená data nejsou nyní započítány skupiny (tedy i dyády).

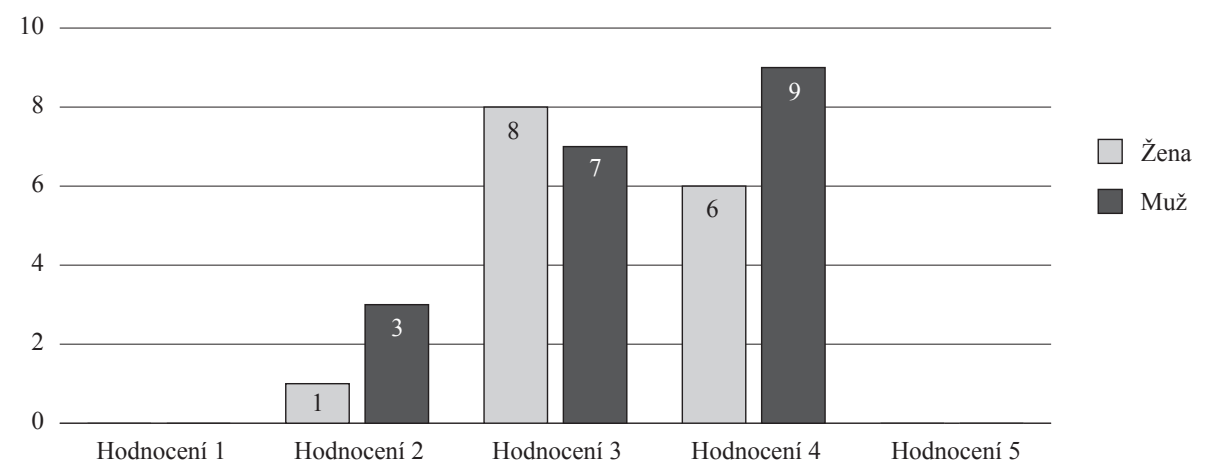

Graf 5 Hodnoceni muslimky napřič pohlavím

Co se týče hodnocení muslimky, nejčetnějším hodnocením ze strany mužských participantů bylo hodnocení 4 (47,4 \%). U žen převládalo průměrné hodnocení, a to v 53 \% prípadů.

Hodnocení muslimky se napříč pohlavím statisticky signifikantně nelišilo. Výsledky hodnocení muslimky ženami a muži $U=149,0 ; p=0,927$, podporuje nulovou hypotézu.

\section{Předpokládáme, že přístup vưči cizince se nebude lišit např́íč pohlavím.}

H0: Př́stup vi̊či cizince se neliší např́íc pohlavím.

HA: Př́stup vůči cizince se liší napříč pohlavím.

Ve druhém bloku, kdy figurantka ztvárňovala cizinku, bylo osloveno 19 žen a 18 mužů. 


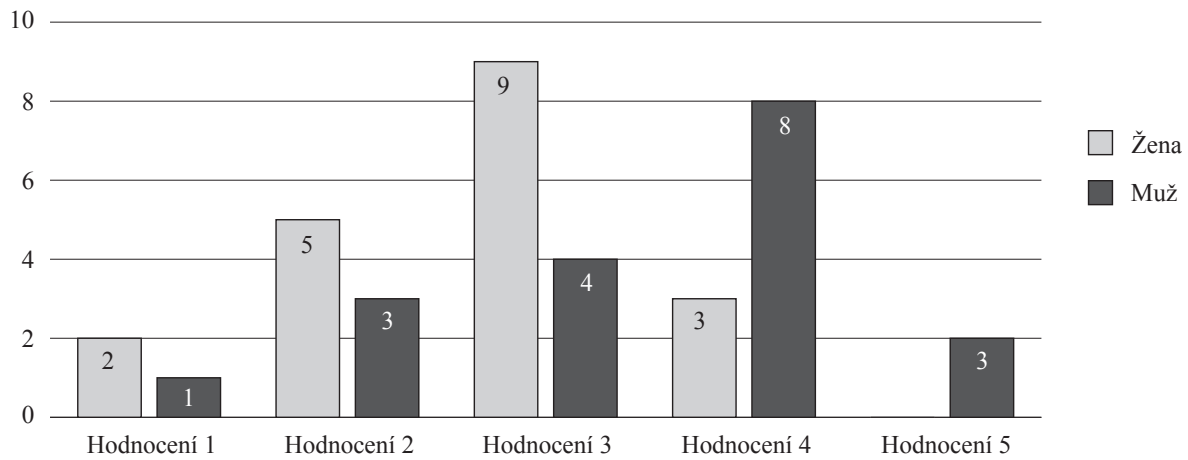

Graf 6 Hodnocení cizinky napríč pohlavím

Hodnocení cizinky bylo více diferencované. Ženy reagovaly na cizinku podprůměrně v 36,8 \% případů a jejich nejčetnějším hodnocením bylo hodnocení 3 . Muži podprůměrně reagovali pouze ve $22 \%$ př́padů a jejich nejčetnějším hodnocením bylo hodnocení 4 .

I přes tyto rozdíly se hodnocení cizinky napříč pohlavím také statisticky signifikantně nelišilo. Výsledky hodnocení cizinky ženami a muži $U=229,0 ; p=0,068$ podporuje nulovou hypotézu.

\section{Předpokládáme, že přístup vůči muslimce se bude lišit mezi jednotlivci a skupinami.}

H0: Přístup vůči muslimce se mezi jednotlivci a skupinami neliší.

HA: Př́istup vưči muslimce se mezi jednotlivci a skupinami liší.

Toto mínění vyšlo z našeho předpokladu, že člověk jedná ve skupině jiným způsobem, než jakým by jednal jako jednotlivec. Ve skupině se projeví fenomény jako např́klad skupinová konformita, a to zejména vůči cizímu (strange) subjektu.

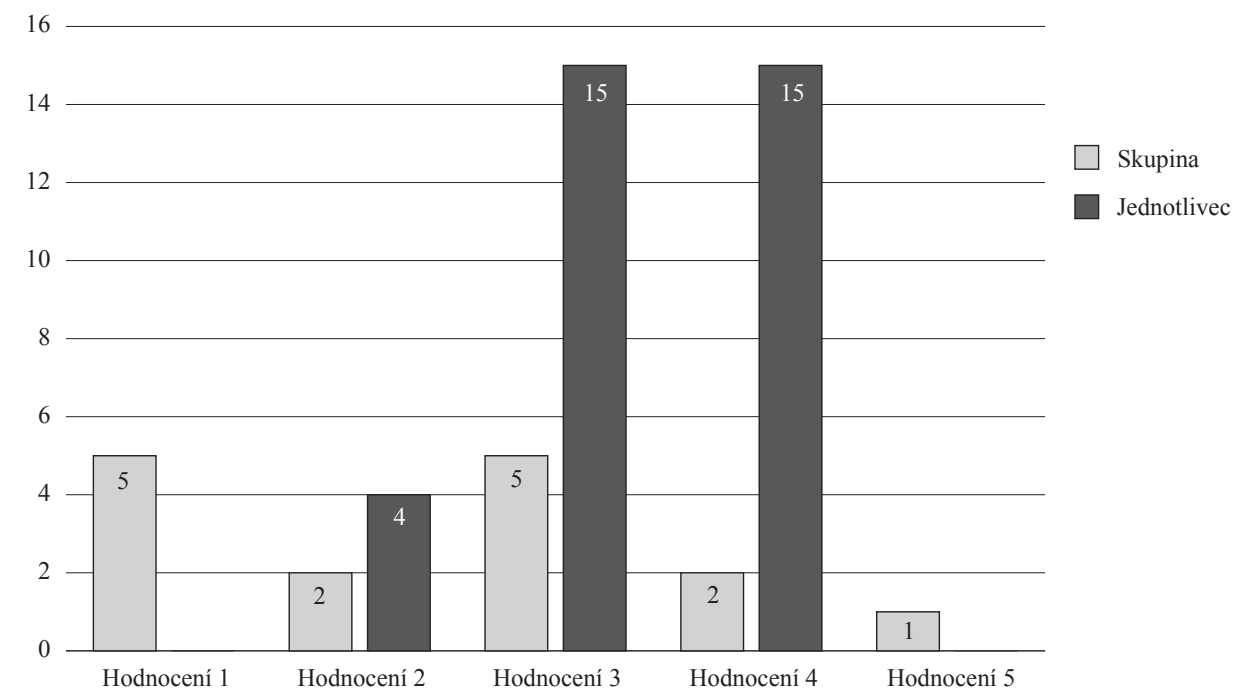

Graf 7 Hodnocení muslimky mezi jednotlivci a skupinami 
V př́padu muslimky bylo osloveno 15 skupin (dyády i vícečlenné skupiny) a 34 jednotlivců.

Skupiny reagovaly podprůměrně v $46,7 \%$ př́ípadů, zatímco jednotlivci reagovali podprůměrně v $11,7 \%$ př́padů.

V př́padě muslimky $\chi^{2}(4, N=49)=18,33 ; \mathrm{p}=0,001$ jsme podpořily alternativní hypotézu, že př́ístup vůči muslimce se liší mezi skupinami a jednotlivci.

\section{Předpokládáme, že př́ístup vůči cizince se nebude lišit mezi jednotlivci a skupinami.}

H0: Př́́stup vůči cizince se mezi jednotlivci a skupinami neliší.

HA: Př́stup vůči cizince se mezi jednotlivci a skupinami liší.

V př́ípadě cizinky jsme nepředpokládaly výrazně odlišné chování skupin, jelikož běžná cizinka je méně neobvyklý subjekt, primárně nevyvolávající předsudky. Výskyt cizince v Praze je také relativně běžným jevem.

V prrípadě cizinky bylo osloveno 13 skupin a 37 jednotlivců.

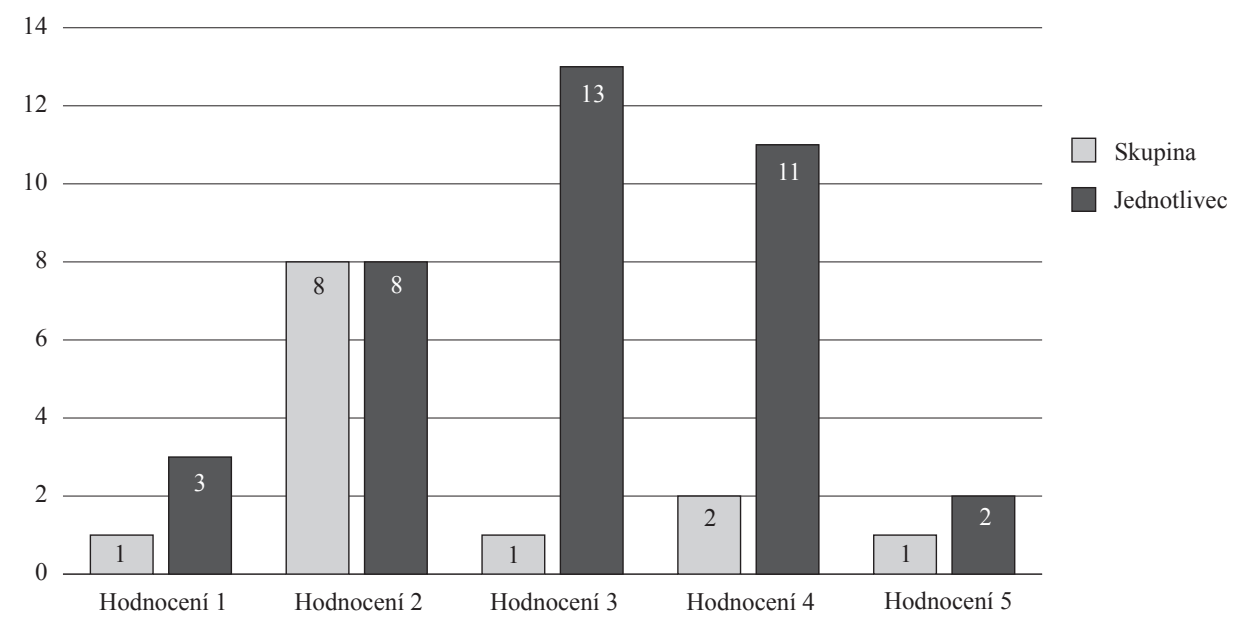

Graf 8 Hodnoceni cizinky mezi jednotlivci a skupinami

Skupiny reagovaly na cizinku také převážně podprůměrně (v 69 \% př́padů), jednotlivci pak pouze $\mathrm{v} 23,4 \%$ prípadů.

V př́ipadě cizinky $\chi^{2}(4, \mathrm{~N}=50)=8,370 ; \mathrm{p}=0,079$, jsme podpořily naši hypotézu. Př́stup jednotlivců a skupin vůči cizince se statisticky významně nelišil.

\section{Diskuze}

Výzkumy na téma postojů vůči cizincům, případně na téma imigrace, jsou v zahraničí četnější než v České republice. Mimo již uvedené, můžeme zmínit výzkum Strabace a kolektivu (2014), kteří zkoumali postoje k muslimům a imigrantům ve čtyřech zemích: Velké Británii, USA, Norsku a Švédsku. V posledních dvou zmíněných zemích nebyly zjištěny téměř žádné rozdíly mezi postoji vůči muslimům a vůči imigrantům, ve 
Velké Británii a USA statisticky signifikantní rozdíly byly, avšak v opačném směru, než výzkumníci očekávali (lidé, kteří se obávali migrace, ji př́mo nespojovali s islámem).

Jak jsme zmiňovaly výše, obava z imigrace je v České republice značná. V našem výzkumu jsme si stanovily za cíl zjistit, zda jsou postoje k cizincům muslimského vyznání statisticky signifikantně odlišné od postojů $\mathrm{k}$ běžným cizincům. Náš výzkum ovšem nepodpořil hypotézu, že jsou tyto postoje odlišné, tedy př́stup k těmto dvěma skupinám cizinců se nelišil. Tak se mohlo stát z toho důvodu, že pozitivní nebo negativní pohled na muslimy jako „,cizince“ není postaven na setkání tvář́ v tvář (verbal encounter face-to-face), spíše se jedná o produkt diskurzu na sociální úrovni (Ahmed, cit. podle Harris et. al. 2016, s. 6). Tyto postoje jsou také z větší části mediovány: názor osoby na muslimy proto může být z jejího pohledu ospravedlněn, jelikož takové postoje byly předtím pozorovány na sociální úrovni. Muslimové se proto zdají být určitými ,známými cizinci“ (familiar stangers). Při setkání z očí do očí (na ulici), jako tomu bylo při našem výzkumu, může u osoby vyvstat konflikt mezi sociálně stanovenými postoji, stavěnými na obavách z terorismu a imigrace, a momentální situací, při které je muslim percipován v jiném kontextu; postoj postavený na základě sociálního diskurzu se tedy hroutí. Na základě různých výzkumů se také liší postoje v souvislosti s prostředím, ve kterém mají být manifestovány. Kontakt na veřejném místě je asociován s nejslaběji vyjadřovanými osobními postoji (Piekut, Valentine, 2017).

\section{Češi versus cizinci}

Mezi Čechy a cizinci jsme nenalezly statisticky signifikantní rozdíl v přístupu, a to jak k figurantce v roli muslimky, tak k figurantce v roli cizinky. Avšak můžeme si všimnout odchylek v reakci na cizinku. Cizinci zde reagovali podprůměrně ve 48 \% prípadi̊, zatímco Češi ve 29,2 \%. Důvodem této reakce by mohl být fakt, že cizinec sám neví, kde se přesně nachází, a tak rovnou odmítá poradit. Na druhou stranu stejně tak by se mohla objevit identifikace s jiným ,ztraceným cizincem“, tím pádem větší ochota pomoci díky empatii. Proč se však tento př́stup neobjevuje analogicky také u figurantky v roli muslimky, stojí za bližší průzkum.

\section{Muži, ženy, skupiny}

Nejpozitivnější (nadprůměrné) reakce na naši figurantku v obou rolích jsme zpozorovaly mezi mužskými participanty, zatímco nejhorší reakce mezi skupinami. Tak se mohlo dít z důvodu, že figurantka byla žena a heterosexuální mužští participanti se mohli snažit figurantku zaujmout svým vystupováním, tedy spojovat akt pomoci s aktem seznámení se. Proč byla však ,̌reč těla“ mužů výraznější, když figurantka vystupovala v roli muslimky, si vysvětlujeme tak, že muslimská žena může vyjadřovat vlastnosti, které muži na ženách obecně oceňují, jako je např́iklad jemnost nebo předpokládaná submisivita. Roli také mohl hrát fakt, že muslimská žena je svým způsobem záhadná a zajímavá. Podprůměrné hodnocení figurantky skupinami by mohly vysvětlovat teorie skupinového chování, které se často odlišuje od chování jednotlivce a souvisí se skupinovou konformitou, difúzí zodpovědnosti a dalšími fenomény. Je však zajímavé, že takové chování se většinou vyskytovalo pouze u větších skupin. Všechny námi oslovené „větší “ skupiny (více než 2 osoby) nikdy nereagovaly ani průměrně, zatímco oslovené skupiny dvou osob (často muž a žena) 
reagovaly více diferencovaně (obdržely hodnocení v rámci celé naší škály). Tato odlišnost v hodnocení skupin může být rozhodně subjektem dalšího zkoumání.

Jsme si vědomy limitů výzkumu. Při opětovném zkoumání bychom doporučily zvýšit počet účastníků a provést jednotlivá měření ve více dnech. Figurantem by mohla být, jak žena, tak i muž a jejich výsledky by mohly být porovnány. Doprovodný tým by se mohl zaměřit na přesné zjištění země původu účastníků, tato informace by mohla sloužit jako případné zdůvodnění jejich reakce (tedy mohli by být porovnáni respondenti ze zemí $\mathrm{s}$ běžnou a velkou muslimskou komunitou a ti, kteří pochází ze zemí bez větší muslimské komunity). Doprovodný tým by mohl nadále zjišt'ovat věk respondentů, jelikož mnohé výzkumy (např. Harris et al., 2016) ukázaly, že negativní komentáře na účet muslimů jsou především od starších respondentů (nad 45 let). Výzkum by také mohl být realizován v jiném prostředí, například ve škole, na pracovišti, prrípadě by mohl být doplněn ještě dotazníkovým šetřením zabývajícím se postoji vůči cizincům a minoritám. Dále se domníváme, že reakce kolemjdoucích by se mohly lišit ve vztahu k velikosti či známosti místa. Respektive bychom doporučily zkusit podobný výzkum i v menším městě či na vesnici.

\section{Závěr}

Cílem našeho výzkumu bylo zjistit, jaké jsou konativní postoje k cizincům s jasným muslimským vyznáním a zda se liší od postojů k cizincům „bez vyznání“. Mezi reakcemi na figurantku v roli muslimky a figurantku v roli cizinky jsme nenašly signifikantní rozdíl, tudíž naše prvotní hypotéza, postavená zejména na současné geopolitické situaci v Evropě, nebyla podpořena. Tento závěr je ovšem z našeho pohledu spíše pozitivní, protože ukazuje, že strach z islámu by mohl být doopravdy konstituován pouze na sociálním dialogu a nezakládá se na (svým způsobem závažnější) osobní zkušenosti.

V reakcích na figurantku v roli muslimky jsme také nepozorovaly téměř žádné hostilní reakce. Hostilní reakci na figurantku v roli muslimky jsme v našem výzkumu zaznamenaly pouze ve $2 \%$ prípadů.

Zajímavým zjištěním bylo, že se statisticky signifikantně nelišilo hodnocení Čechů a hodnocení cizinců. U cizinců jsme zvláště vůči figurantce v roli muslimky předpokládaly pozitivnější přístup než u Čechů. Z našich dat je ale možno vyčíst, že hodnocení Čechů bylo průměrně lepší než hodnocení cizinců. Tento závěr, ač nepodporuje naši hypotézu, se nám zdá velmi pozitivní, jelikož by mohl znamenat, že Češi nemají tak silně citově zabarvené (vysoce emotivní) postoje vůči muslimům, tedy takové, jaké nám předkládají média a na kterých parazitují některá politická hnutí a politické strany.

Velmi zajímavým výsledkem bylo podpoření hypotézy, že skupiny se vůči muslimům chovají více vyhraněně. Hodnocení skupin bylo v porovnání s hodnocením jednotlivců (kdy muži - jednotlivci reagovali na figurantku „nejlépe“) vysoce podprůměrné. Naše hypotéza rozdílnosti v prrístupu skupin tedy byla podpořena, což také svým způsobem může zdůvodňovat, proč se předsudky vůči muslimům tvoří především na základě sociálního dialogu, přitom tváří v tvář u jednotlivce nejsou reakce tak vyhraněné. Tato otázka by zasloužila další výzkum.

Současná situace v Evropě tedy otevírá dveře dalším výzkumům této problematiky, a to především ve státech, ve kterých nejsou zkušenosti s muslimskou minoritou. Lepší 
pochopení tohoto vysoce aktuálního tématu může osvětlit důvod úspěchu či neúspěchu různých sociálních programů, právních předpisů a mezinárodních dohod a do budoucna samozřejmě i zlepšení v těchto zásadních oblastech.

\title{
LITERATURA
}

Allen, C., Nielsen, J. (2002). Summary Report on Islamophobia in the EU after 11 September 2001. Vienna: EUMC.

Biben, M. V Česku žije 22 tisíc muslimů. Jsou však dobře integrování, míní expert. [Vyhledáno 14. 2. 2016 na http://zpravy.idnes.cz/uz-nyni-zije-v-cesku-22-tisic-muslimu-dbv-/domaci .aspx?c=A151004_214621_domaci_fka]

Červenka, J. Veřejnost o svých obavách a bezpečnostních rizicích pro Českou republiku prosinec 2016. [Vyhledáno 17. 2. 2017 na http://cvvm.soc.cas.cz/vztahy-a-zivotni-postoje /verejnost-o-svych-obavach-a-bezpecnostnich-rizicich-pro-ceskou-republiku-prosinec-2016]

Esposito, J. L., Kalin, I. (2011). Islamophobia: The Challenge of Pluralism in the 21st century. Oxford: Oxford University press.

Harris, C., Jackson, L., Piekut, A., Valentine, G. (2016). Attitudes towards the 'stranger': negotiating encounters with difference in the UK and Poland. Social and Cultural Geography, 18(1), 16-33.

Heringa, A., Bolt, G., Dijst, M. (2013). Strategies of avoidance and belonging: Meanings of spatiotemporal whereabouts and responses to encounters with 'the other'. Paper presentation presented at the International and Interdisciplinary Conference on Emotional Geographies, 1-3 July 2013, University of Groningen, The Netherlands.

JASP Team (2016). JASP (Version 0.8.0.0) [Computer software].

LaPiere, R. T. (2010). Attitudes vs Actions. International Journal of Epidemiology, 39(1), 7-11.

Lofland, L. H. (1973). A world of strangers: Order and action in urban public space. Illinois: Waveland Press.

Ministerstvo pro místní rozvoj ČR, Czech tourism (2015). Př́ijezdový cestovní ruch 2015. [Vyhledáno 17. 2. 2017 na http://www.mmr.cz/getmedia/1950f0c2-ef53-4986-b546 5fb528b4dfdf/Prezentace-Prijezdovy-cestovni -ruch-za-4-ctvrtleti-a-rok-2015.pdf]

Nolen-Hoeksema, S., et al. (2012). Psychologie Atkinsonové a Hilgarda. Praha: Portál.

Piekut, A., Valentine, G., Andersson, J. (2017). Spaces of encounter and attitudes towards difference: A comparative study of two European cities. Social Science Research, 62(2), 175-188.

Spruyt, B., Elchardus, M. (2012). Are anti-Muslim feelings more widespread than anti-foreigner feelings? Evidence from two split-sample experiments. Ethnicities, 12(6), 800-820.

Strabac, Z., Aalberg, T., Valenta, M. (2013). Attitudes towards Muslim Immigrants: Evidence from Survey Experiments across Four Countries. Journal of Ethnic and Migration Studies, 40(1), 100-118.

Vágnerová, M. (2005). Základy psychologie. Praha: Karolinum.

Výrost, J., Slaměník, I. (1997). Sociální psychologie. Praha: ISV.

\section{LOST IN PRAGUE: THE ATTITUDES OF PASSERS-BY TO A PERSON OF MUSLIM RELIGION}

\author{
K. SMUŽANICA, K. STOJANOVÁ
}

\section{ABSTRACT}

The current geopolitical situation in Europe raises the question of what attitudes towards Muslims are. This article deals with the attitudes of people in Prague to a foreign woman whose Muslim belief is obvious compared to a stranger, whose particular worldview cannot be determined. A total of one hundred people were approached. Fifty of them were addressed by a figurant serving as a Muslim woman, another fifty by the same figurant in 
the role of "ordinary" stranger. The responses of individuals were rated on a scale of one to five. The attitude of people to the figurant in the role of the Muslim woman did not differ statistically significantly from the attitude towards figurant in the role of foreigner $(p=0.124)$. Other aspects of this issue, such as the difference between the evaluation of Czechs and foreigners, are discussed.

Key words: attitudes, Muslim, foreigners, Prague, prosocial behavior

O autorkách: Kateřina Smužanica je studentkou Filozofické fakulty Univerzity Karlovykatedry Psychologie. E-mail: katherinadvorak@gmail.com; Klára Stojanová je studentkou Filozofické fakulty Univerzity Karlovy - katedry Psychologie a Právnické fakulty UniverzityKarlovy.E-mail: klara.stojanova@centrum.cz 